\title{
Effects of simulated underwater vehicle lighting on fish behavior
}

\author{
Clifford H. Ryer*, Allan W. Stoner, Paul J. Iseri, Mara L. Spencer \\ NOAA Fisheries, Alaska Fisheries Science Center, Fisheries Behavioral Ecology Program, Hatfield Marine Science Center, \\ Newport, Oregon 97365, USA
}

\begin{abstract}
Little is known regarding bias attributable to fish behavior for visual transects conducted using underwater vehicles (UVs). Experiments were conducted under 2 ambient illuminations to assess the behavioral responses of 7 north Pacific Ocean groundfish species to a light stimulus that simulated the approach of a UV. Species included sablefish Anoplopoma fimbria, Pacific halibut Hippoglossus stenolepis, lingcod Ophiodon elongatus and 4 species in the genus Sebastes: blue rockfish $S$. mystinus, black rockfish $S$. melanops, copper rockfish $S$. caurinus and quillback rockfish $S$. maliger. Movement, as well as general activity, varied greatly between species. The most active species, sablefish, became agitated and moved away from the looming light source, while the least active species, Pacific halibut and lingcod, typically remained stationary. Of the 4 rockfish species, 2 demonstrated a strong response to ambient light level. Black rockfish and blue rockfish moved away from the looming light source, but avoidance was delayed under high ambient light. Bias probably differs among species, being greatest for those that are highly active and mobile, like sablefish. Further, ambient light may modulate bias, such that researchers need to be cautious about comparing results for surveys conducted at different depths and/or times of day.
\end{abstract}

KEY WORDS: Fish behavior · Light response $\cdot$ Survey bias $\cdot$ Gear avoidance $\cdot$ ROV $\cdot$ Submersible

\section{INTRODUCTION}

Demersal finfish and crustacean surveys are increasingly being conducted with underwater vehicles (UVs), both manned and unmanned (Stoner et al. 2008). The advantage of using traditional fishing gear (trawls, longlines and pots) is that they are relatively inexpensive to operate and provide integrated data across broad spatial scales; however, they are restricted to the seafloor where topographic relief is low. Because observations of fish behavior, spatial distribution and interactions with habitat can provide insight into the function of essential fish habitat, UVs can be used over areas of the seafloor where topographic relief is high and where traditional gear could become entangled or disturb the bottom habitat.

For trawls, survey bias can be attributed to avoidance and/or escape behavior (Ryer 2008), which may be in- fluenced by ambient illumination and water temperature (Woodhead 1964a,b, Ryer \& Barnett 2006). Effort has been directed towards correcting trawl catch data to obtain accurate abundance estimates (e.g. Dickson 1993). Capture efficiency of baited gear is also influenced by fish behavior, which varies with temperature, light, current and fish density (Auster 1985, Stoner 2004). Although direct-count observations from submersibles have sometimes been used to estimate absolute densities of fish for comparison with traditional survey gear (e.g. Uzmann et al. 1977, Adams et al. 1995, Krieger \& Sigler 1996), little is known regarding bias associated with UVs. Stoner et al. (2008) summarized observations on 48 finfish species (22 families); 25 species were attracted to UVs, while 30 exhibited avoidance. Nine species demonstrated both attraction and avoidance, depending upon the particular study and/or conditions. 
Due to the efficiency of sound propagation in water, fish will probably first detect the sound generated by an approaching UV. Most fish have hearing in the range of 300 to $1000 \mathrm{~Hz}$ (Popper 2003), and both electric and hydraulic thrusters probably emit sound in this frequency range. Gadids and herring respond to approaching surface vessels with both diving and horizontal movements (Vabø et al. 2002, Handegard et al. 2003, Handegard \& Thøstheim 2005). Similarly, fish may elicit avoidance behavior in response to the noise generated by trawl warps and doors (Handegard \& Thøstheim 2005).

Artificial lighting also constitutes a major stimulus likely to influence fish; nearly all UVs use lights for video and still photography. As an object or light approaches, the projected image on the observer's retina expands, a process referred to as visual looming (Schiff et al. 1962), which frequently triggers avoidance behaviors in animals. In the ecological literature, this has been applied in the context of predator-prey interactions, and has been used to examine factors such as perception of predator size and prey-reactive distances (Domenici 2002, Paglianti \& Domenici 2006). As a UV approaches, the lights from the vehicle will appear to loom to a fish, and as with trawls (Ryer 2008), may be interpreted by the fish as a threat, resulting in avoidance behavior. Alternatively, under some conditions fish are attracted to underwater lights. We frequently use drop-lights to attract and capture juvenile gadids in the field (C. Ryer pers. obs.). Yet, most studies using UVs assume that avoidance or attraction behavior by fish does not introduce bias that would significantly influence study conclusions.

Another factor rarely considered is ambient illumination. The increasing use of remotely operated vehicles (ROVs) means that the vehicle need only be brought up from the bottom for maintenance or when transferred to a new station. Hence, data are often acquired from different depths or times of day, with little consideration of how this may influence fish behavior. Ambient illumination influences many aspects of fish behavior: prey capture, habitat associations, schooling and predator avoidance (Ryer \& Olla 1998, 1999, Petrie \& Ryer 2006). Therefore, fish may respond differently to the looming stimuli associated with an approaching UV, depending upon season, depth, time of day, water clarity and meteorological conditions.

Here we report the reaction of 7 groundfish species to the light stimuli associated with simulated UV approach and subsequent retreat. We chose to examine light because it represented a more tractable problem than sound, which in our estimation would require highly specialized apparatus and experimental conditions. We examined sablefish Anoplopoma fimbria, Pacific halibut Hippoglossus stenolepis, lingcod
Ophiodon elongatus and 4 members of the genus Sebastes: blue rockfish $S$. mystinus, black rockfish $S$. melanops, copper rockfish $S$. caurinus and quillback rockfish $S$. maliger. With the exception of sablefish, we examined each species under 2 ambient illuminations, approximating the ambient light found at 55 and $70 \mathrm{~m}$ depths. More specifically, we tested the hypothesis that fish will react more strongly to simulated UV approach under low rather than high ambient light conditions.

\section{MATERIALS AND METHODS}

Apparatus and experimental protocols. Rockfishes, lingcod and sablefish were captured as either juveniles or adults in Oregon coastal waters of the Pacific Ocean. Pacific halibut were captured as juveniles off Kodiak, Alaska, and then reared at the Hatfield Marine Science Center in Newport, Oregon. Fish were maintained on a $12 \mathrm{~h}$ light:12 h dark photoperiod (lights on at 07:00 h, off at 19:00 h) during both holding and experimentation periods.

Exposure to simulated vehicle approach or retreat took place in an elongated tank $(10.7 \mathrm{~m}$ long $\times 1.5 \mathrm{~m}$ wide $\times 1.2 \mathrm{~m}$ high) filled to a depth of $0.9 \mathrm{~m}$ and provided with flow-through seawater (salinity: 28 to 35). This tank (Fig. 1) was located in a light-proof room. One end of the tank was fitted with a $24 \mathrm{~cm}$ diameter transparent bulkhead fitting. A mechanical iris and a rheostat-controlled halogen light in a light-proof housing were attached to the exterior tank wall behind this bulkhead. Fish were contained within a $4.8 \mathrm{~m}$ section of the tank that was enclosed by a transparent partition at one end, and a dark partition at the other (Fig. 1). The bottom of this section was left bare, except for Pacific halibut trials, when it was covered with sand to a depth of $4 \mathrm{~cm}$ to allow the halibut to bury themselves. For lingcod and rockfish, there were 6 concrete blocks $(40 \times 20 \times 9 \mathrm{~cm})$ added to provide physical structure; these were evenly distributed along the bottom, with their long sides turned perpendicularly to the light source.

Fish were introduced into the experimental tank 3 to $5 \mathrm{~d}$ before trials and fed daily. Of the species examined, adult sablefish occur at the greatest depths (300 to $1000 \mathrm{~m}$, Mecklenburg et al. 2002) and were subjected to the looming/retrogression (simulated vehicle approach/retreat) sequence in darkness $(<1 \times$ $10^{-8} \mu \mathrm{mol}$ photons $\mathrm{m}^{-2} \mathrm{~s}^{-1}$ ). The other species occur at shallower depths, and depending upon depth, time of day, water clarity and meteorological conditions, would experience variations in visible light. For these, each group was subjected to the looming/retrogression sequence under high and low ambient illuminations on 

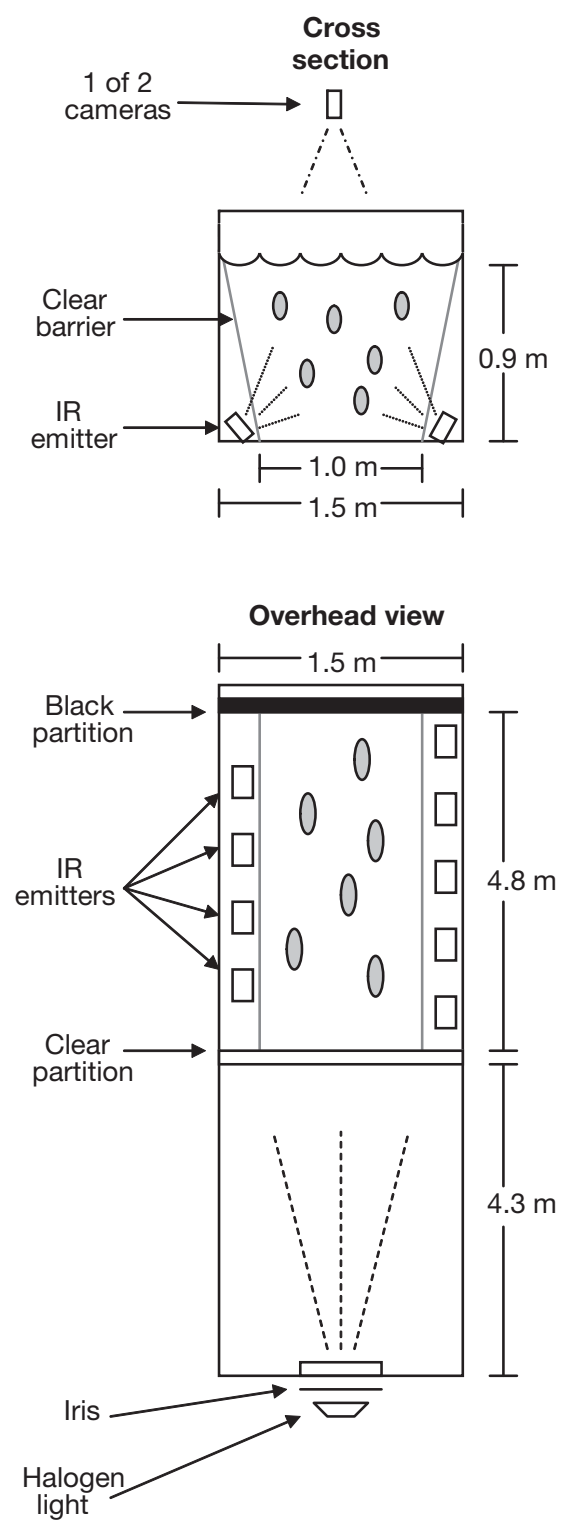

Fig. 1. Diagram (not to scale) of looming light apparatus detailing relative positions of the fish containment area, looming light source, infrared (IR) emitters and cameras, in both cross-sectional and overhead views

alternate days; the order was alternated for each successive group. Low ambient light level $\left(6.3 \times 10^{-5} \mu \mathrm{mol}\right.$ photons $\mathrm{m}^{-2} \mathrm{~s}^{-1}$ ) was produced with a green $(555 \mathrm{~nm})$ light-emitting diode (LED) bulb in a reflective cone placed alongside the tank and aimed towards the ceiling. High ambient illumination $\left(2.1 \times 10^{-3}\right.$ umol photons $\mathrm{m}^{-2} \mathrm{~s}^{-1}$ ) was achieved using a $60 \mathrm{~W}$ white incandescent bulb. We did not measure the emission spectrum of this white light, but it clearly emitted over a broader visual spectrum than did the green LED bulb. We assume that the 2-fold order of magnitude change in quanta between these 2 light sources had more of an effect on the visual perception of ambient light by the species examined than did the particulars of spectral sensitivity of these species. Both produced relatively even illumination throughout the confinement section. Light was measured on the bottom and center of the section containing fish measurements with an IL1700 Research Radiometer, equipped with a photosynthetically active radiation (PAR)-filtered, cosine response, underwater detector, sensitive to $1 \times$ $10^{-8} \mu \mathrm{mol}$ photons $\mathrm{m}^{-2} \mathrm{~s}^{-1}$. For each trial, the appropriate light level was set at 07:00 h on the day of the trial. This 2-fold order of magnitude difference between high and low ambient illumination corresponded to a depth change from 55 to $69 \mathrm{~m}$, assuming a daytime sea surface light level of $2000 \mu \mathrm{mol}$ photons $\mathrm{m}^{-2} \mathrm{~s}^{-1}$ and a light extinction coefficient of 0.25 , a value characteristic of coastal shelf waters in the eastern north Pacific Ocean (C. Ryer pers. obs.). With sea surface light varying as much as 8 orders of magnitude during a diel cycle, this 2-fold order of magnitude change at depth would be consistent with minor meteorological changes (clear sky versus cloudy) or the difference between daylight and dusk.

During each trial (replicate), vehicle approach was simulated over an 8 min sequence during which light projected through the transparent bulkhead gradually increased approximately by 8 orders of magnitude over 4 min (looming sequence), followed by gradual decrease over another 4 min (retrogression). We assumed that fish would first perceive a simulated underwater vessel (SUV) at approximately $60 \mathrm{~m}$. With the SUV progressing at $0.26 \mathrm{~m} \mathrm{~s}^{-1}$, it would take 4 min to reach a stationary fish, although water clarity, SUV lighting and speed would influence ambient light and fish sensitivity would influence this relationship. At 09:30 h, with the iris set at its smallest aperture $(0.5 \mathrm{~cm})$, the halogen light intensity was gradually increased over 2 min to full intensity. Next, the iris was gradually opened to its full aperture $(15 \mathrm{~cm})$ over 2 min. Immediately upon reaching full aperture of the iris, the reverse sequence was initiated simulating vehicle retreat. Using electronic controls for the halogen light and a calibrated mechanical iris control mechanism, this looming/retrogression sequence was exactly replicated during each trial. Illumination in the tank rose from $<1 \times 10^{-8}$ at the onset, to $0.6 \mu \mathrm{mol}$ photons $\mathrm{m}^{-2} \mathrm{~s}^{-1}$ at the conclusion of the looming sequence. For these measurements the radiometer detector was positioned in the middle of the water column in the center of the confinement area, facing the looming light. After a trial was completed, the lights in the room were reset to appropriate daytime light levels, depending on the species. This entire process was repeated the following day using the 
opposite lighting from the previous day. After the last trial, fish were removed and measured for total length (TL).

Two video cameras were positioned over the tank, each viewing $1 / 2$ of the confinement area. Digital video records of trials began 20 min before the initiation of the looming sequence and terminated 20 min after completion of the retrograde sequence. Imaging of fish during this period was made possible by 9 infrared (IR) LED emitters $(60 \mathrm{~W})$ positioned along either side of the tank bottom, and aimed upward so that they illuminated the section where the fish were located. These IR emitters produced light at a wave length of $\geq 760 \mathrm{~nm}$; previous work has established that fish are insensitive to light in this range (John 1964, Pitcher and Turner 1986, Hlggs and Fuiman 1996). IR emitters were turned on and off at the same time as the video recorders.

Species specific protocols. Five replicate groups of 3 yr old sablefish ( $70 \mathrm{~cm}$ TL) 6 fish to a group, were tested. For both black rockfish and blue rockfish, 5 groups of each species were tested with 6 fish in each group. Mean total length (TL) was $43.9 \mathrm{~cm}$ (range: 40 to $50 \mathrm{~cm}$ ) for black rockfish and $37.7 \mathrm{~cm}$ (range: 31 to $42 \mathrm{~cm}$ ) for blue rockfish. Five pairs of copper rockfish were tested (mean TL $=42.65 \mathrm{~cm}$, range: 33.5 to $49 \mathrm{~cm}$ ), as were 3 pairs of quillback rockfish (mean $\mathrm{TL}=39.5 \mathrm{~cm}$, range: 33 to $51 \mathrm{~cm}$ ). Each pair of quillback rockfish was tested twice. Four pairs of lingcod (mean TL $=61.6 \mathrm{~cm}$, range: 55 to $65 \mathrm{~cm}$ ) were tested, and 5 groups ( 6 fish each) of Pacific halibut (mean TL = $43.7 \mathrm{~cm}$, range: 38 to $48 \mathrm{~cm}$ ) were also tested.

Video and statistical analysis. Video recordings were analyzed for a $16 \mathrm{~min}$ period: a $4 \mathrm{~min}$ pre-looming period, the $4 \mathrm{~min}$ looming and retrogression sequences, and a 4 min post-retrogression period. Playback of video recordings from each camera was synchronized and displayed on 2 monitors positioned side by side, allowing fish to be individually tracked from 1 screen to the other. The image on each monitor was overlaid with a transparent acetate sheet marked with calibrated grid lines. The coordinates of each fish were recorded every $10 \mathrm{~s}$ throughout the $16 \mathrm{~min}$. These coordinates were used to determine the distances from each fish to the transparent barrier, distances to cinder blocks, inter-fish distances and to calculate activity levels based on location changes.

Sablefish were considerably active; in $10 \mathrm{~s}$ a fish could swim down the length of the tank and back again, so an additional measure of activity was conducted during periods when sablefish were particularly active. A grid divided into 4 squares lengthwise and 2 widthwise was superimposed over the image of each tank half. Two fish were selected at random and the total number of times each fish crossed a line into an adjacent box was recorded over consecutive $10 \mathrm{~s}$ focal periods. This line-crossing activity measure was completed during the following periods; for $1 \mathrm{~min}$ before the looming sequence, the first $3 \mathrm{~min}$ of the looming sequence, the last 2 min of retrogression and 2 min immediately after retrogression. Distance and activity data were averaged across individuals for each pair or group (i.e. replicate).

Barrier-distance data were analyzed by means of separate repeated measure ANOVAs for each of the 4 min periods (pre-looming, looming, retrogression and post-looming). Thus, for each $4 \mathrm{~min}$ period we analyzed the position of fish over 24 discrete steps $(10 \mathrm{~s}$ intervals). For inter-fish distances (distance to nearest neighbor for groups), block distances (distance to nearest cement block) and activity, data were averaged over 1 min intervals and analyzed by repeated measure ANOVA over the entire course of the trial (i.e. $16 \mathrm{~min})$. Where significant ANOVA results were obtained, Tukey's pairwise multiple comparisons were conducted. Statistical results were considered significant at the $\mathrm{p}<0.05$ level.

\section{RESULTS}

\section{Sablefish}

During the pre-looming period, sablefish swam slowly up and down the tank. At $30 \mathrm{~s}$ into the looming sequence (SUV approach) sablefish moved farther from the barrier (Fig. 1, Tukey's test comparisons: $\left.F_{23,92}=2.24, \mathrm{p}=0.004\right)$. This movement was accompanied by increased activity (Fig. 2b), as measured by distance moved over $10 \mathrm{~s}$ intervals (Tukey's test: $F_{15,60}$ $=2.04, \mathrm{p}=0.027$ ), but was better captured by the number of line-crossings per second, which increased 3 -fold (Tukey's test: $F_{3,12}=6.76, \mathrm{p}=0.006$ ). The relatively high fish activity was also indicated by the sound of frequent 'thuds' as sablefish collided with tank walls. Half way through the looming sequence activity decreased as the light reached its maximum (Tukey's test for line-crossings, $p<0.05$ ) and fish moved back towards the barrier (Tukey's test, p < 0.05). During the retrogression sequence (simulating vehicle retreat), sablefish slowly retreated from the barrier, then moved rapidly during the final $70 \mathrm{~s}$, although this was not statistically significant $\left(F_{23,92}=\right.$ 1.53, $\mathrm{p}=0.081$ ), resulting in post-retrogression distances comparable with those of the pre-looming period. Similarly, activity declined through the final 2 min of the retrogression sequence and into the postretrogression period (Tukey's test for line-crossings: $\left.F_{3,12}=11.11, \mathrm{p}=0.001\right)$. 


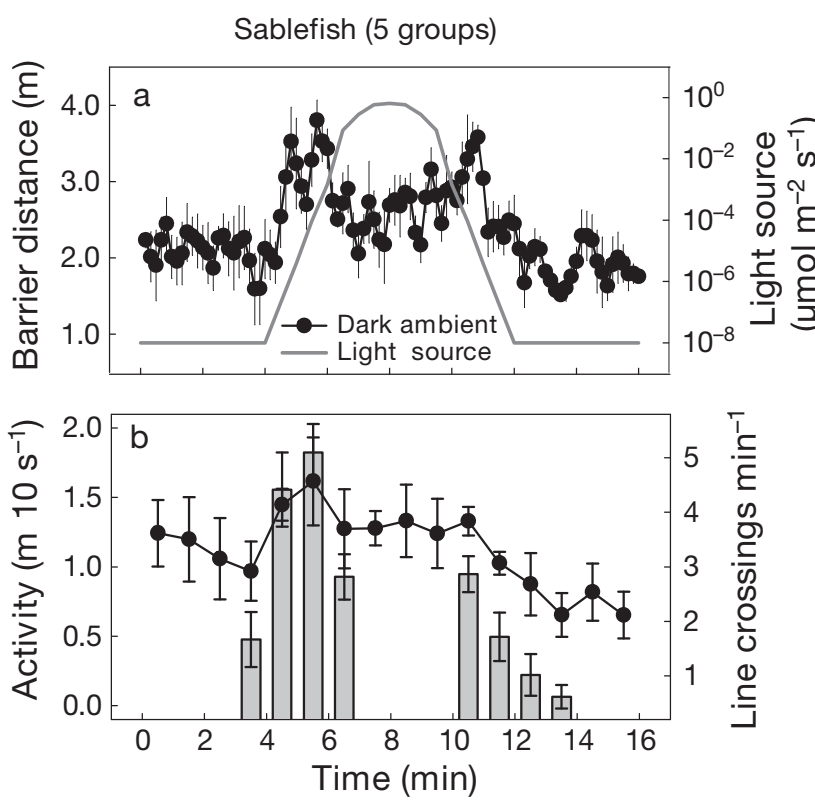

Fig. 2. Anoplopoma fimbria. (a) Mean distance $( \pm$ SE) of sablefish to transparent barrier separating them from the looming light source during pre-looming (0 to $4 \mathrm{~min}$ ), looming (4 to $8 \mathrm{~min})$, retrogression (8 to $12 \mathrm{~min}$ ) and post-retrogression (12 to $16 \mathrm{~min})$ periods, under low ambient $\left(<1 \times 10^{-8} \mu \mathrm{mol}\right.$ photons $\mathrm{m}^{-2} \mathrm{~s}^{-1}$ ) illumination. Light attributable to the looming light source (ambient light absent) is plotted in gray and numerated on the right-hand $y$-axis. (b) Mean activity $( \pm \mathrm{SE})$ of sablefish as measured by coordinate method (points and line) and line-crossing method (bars)

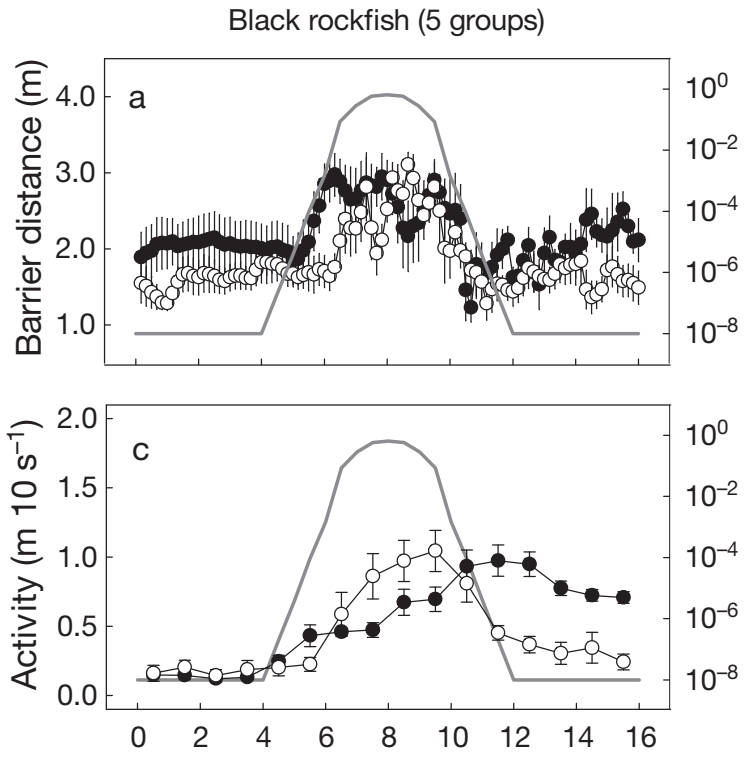

\section{Black rockfish and blue rockfish}

Ambient illumination strongly influenced how both black rockfish (BLK) and blue rockfish (BLU) responded to SUV approach (Fig. 3). Fish became more active during the looming sequence and moved away from the barrier, but the timing differed between illumination treatments, i.e. an illumination $\times$ time interaction (BLK activity: $F_{15,60}=12.84, \mathrm{p}<0.001$; BLK barrier distance: $F_{23,92}=3.15, \mathrm{p}<0.001$; BLU activity: $F_{15,60}=$ 1.95, $\mathrm{p}=0.035$; BLU barrier distance: $F_{23,92}=8.06, \mathrm{p}<$ 0.001). Under low ambient illumination fish shifted position, either immediately (BLU) or approximately 1 min into the looming sequence (BLK). However, under higher ambient illumination this reaction was delayed (Tukey's test, $\mathrm{p}<0.05$ ). This was particularly apparent in BLU, where fish in the dark had begun to move back towards the barrier just as fish in the light began moving away (Tukey's test, $\mathrm{p}<0.05$ ). During the retrogression sequence both species moved back towards the barrier (BLK: $F_{23,92}=4.52, \mathrm{p}<0.001$; BLU: $F_{23,92}=2.43, \mathrm{p}=0.002$ ), culminating in barrier distances comparable with those during the pre-looming period. Neither species engaged in the rapid darting or frantic milling as seen in sablefish. Instead, rockfish either hovered or demonstrated slow directed swimming. Although fish shifted position earlier in the low illumination treatment, activity increased earlier in the high illumination treatment (Tukey's test, p < 0.05).

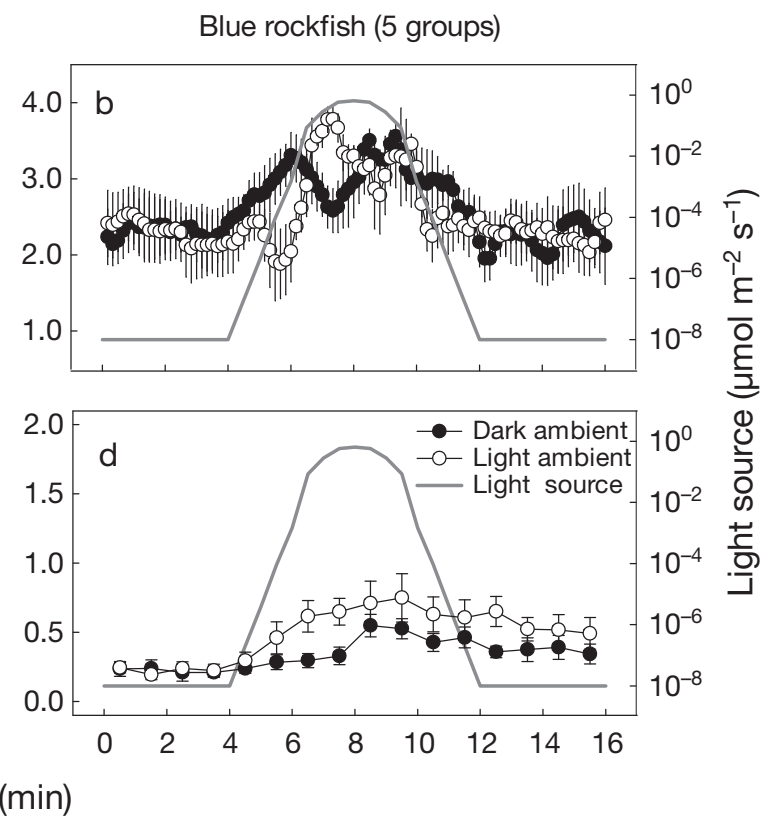

Fig. 3. Sebastes melanops and S. mystinus. Mean distance $( \pm \mathrm{SE})$ to transparent barrier for (a) black rockfish and (b) blue rockfish during pre-looming (0 to $4 \mathrm{~min}$ ), looming (4 to $8 \mathrm{~min}$ ), retrogression (8 to $12 \mathrm{~min}$ ) and post-retrogression (12 to $16 \mathrm{~min}$ ) periods, under both low $\left(6.38 \times 10^{-5} \mu \mathrm{mol}\right.$ photons $\left.\mathrm{m}^{-2} \mathrm{~s}^{-1}\right)$ and high ambient $\left(2.05 \times 10^{-3} \mu \mathrm{mol}\right.$ photons $\left.\mathrm{m}^{-2} \mathrm{~s}^{-1}\right)$ illumination. Mean activity $( \pm \mathrm{SE})$ of (c) black rockfish and (d) blue rockfish. For all 4 panels, light levels attributable to the looming light source (ambient light absent) are plotted in gray and numerated on the right-hand $y$-axis 


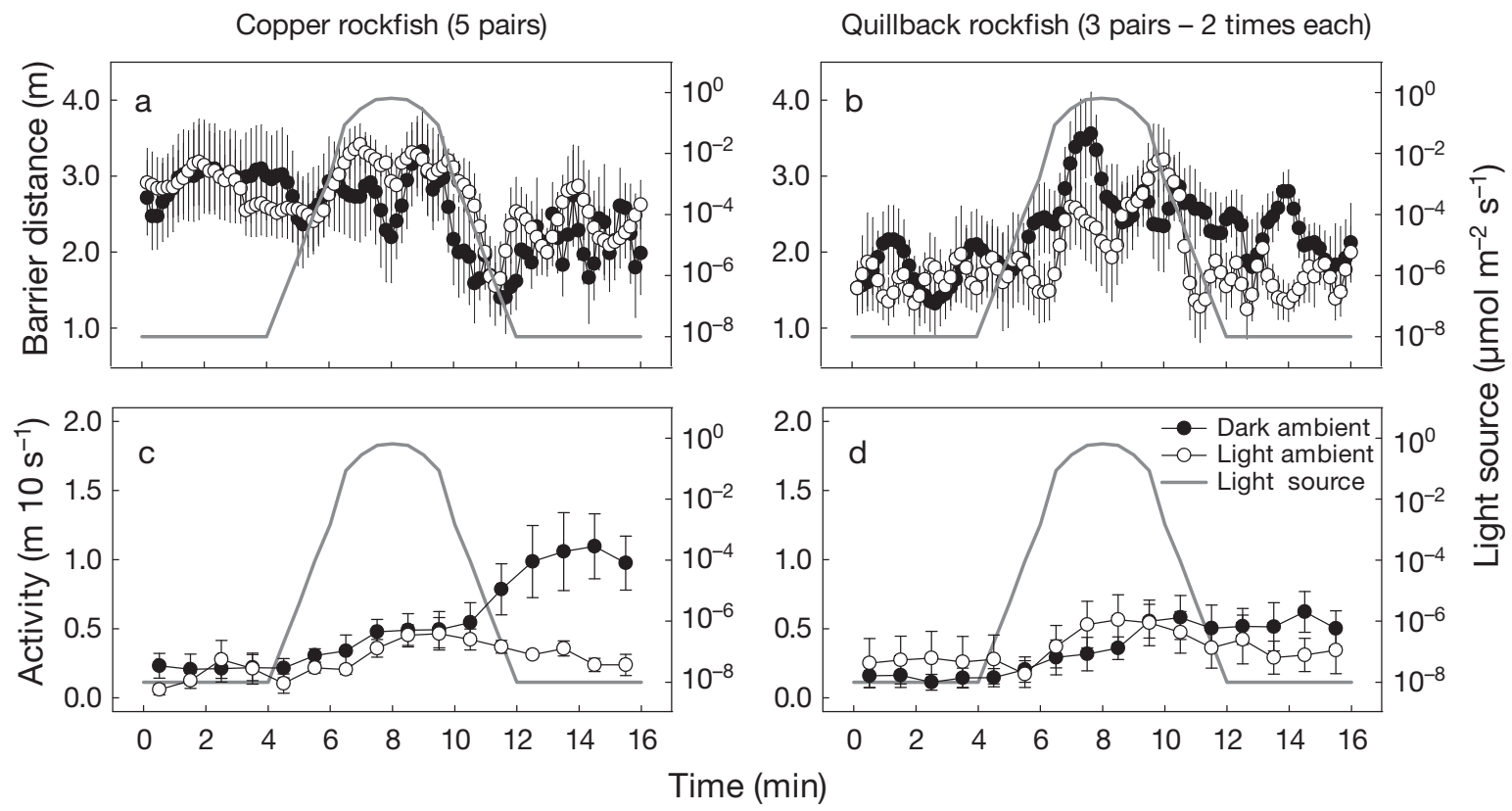

Fig. 4. Sebastes caurinus and S. maliger. Mean distance $( \pm \mathrm{SE})$ to transparent barrier for (a) copper rockfish and (b) quillback rockfish during pre-looming ( 0 to $4 \mathrm{~min}$ ), looming (4 to $8 \mathrm{~min}$ ), retrogression (8 to $12 \mathrm{~min}$ ) and post-retrogression (12 to $16 \mathrm{~min}$ ) periods, under both low $\left(6.38 \times 10^{-5} \mu \mathrm{mol}\right.$ photons $\left.\mathrm{m}^{-2} \mathrm{~s}^{-1}\right)$ and high ambient $\left(2.05 \times 10^{-3} \mu \mathrm{mol}\right.$ photons $\left.\mathrm{m}^{-2} \mathrm{~s}^{-1}\right)$ illumination. Mean activity $( \pm$ SE) of (c) copper rockfish and (d) quillback rockfish. For all 4 panels, light levels attributable to the looming light source (ambient light absent) are plotted in gray and numerated on the right-hand $y$-axis

Furthermore, BLU activity stayed high during the retrogression and post-retrogression periods, and was higher under high ambient illumination (Tukey's test, $\mathrm{p}<0.05$ ). In contrast, BLK in the high illumination treatment decreased activity during the retrogression sequence, while activity in the low illumination treatment remained high (Tukey's test, $\mathrm{p}<0.05$ ).

\section{Copper rockfish and quillback rockfish}

Both copper rockfish $(\mathrm{CO})$ and quillback rockfish (QB) changed position relative to the barrier during the looming sequence (CO: $F_{23,92}=1.87, \mathrm{p}<0.019$; QB: $F_{23,46}=2.22, \mathrm{p}=0.011$ ) (Fig. 4). Although there were no significant differences between barrier distances at any 2 points in time (Tukey's test), we interpret the ANOVA results as indicative of generalized movement away from the barrier during the looming sequence. During retrogression, $\mathrm{CO}$ moved back towards the barrier $\left(F_{23,92}=4.50, \mathrm{p}<0.001\right)$, regardless of ambient illumination $\left(F_{1,4}=0.73, \mathrm{p}=0.442\right.$; illumination $\times$ time: $\left.F_{23,92}=0.53, \mathrm{p}=0.959\right)$. Among QB there was no significant movement back towards the barrier during retrogression $\left(F_{23,46}=0.87, \mathrm{p}=0.634\right)$. However, QB under low ambient illumination were farther from the barrier that those under high illumination $\left(F_{1,2}=31.92, \mathrm{p}=\right.$ 0.023 ; no illumination $\times$ time interaction: $F_{23,26}=1.06$, $\mathrm{p}=0.423)$.
Ambient illumination influenced the time course of activity for $\mathrm{CO}$ (illumination $\times$ time interaction: $F_{15,60}=$ $2.71, \mathrm{p}=0.003)$. Under low illumination, fish activity gradually increased through the looming and retrogression sequences, but reached peak levels during the post-retrogression period (Tukey's test, $\mathrm{p}<0.05$ ). In contrast, there was increased activity through the looming sequence under high illumination, but a decreased activity during retrogression and afterwards (Tukey's test, $\mathrm{p}<0.05$ ). Illumination also influenced activity for QB (illumination $\times$ time interaction: $F_{15,30}=$ $2.96, \mathrm{p}=0.006)$. There was a tendency for activity to increase during the looming sequence. Superimposed upon this was a tendency for fish to be more active under high than under low ambient illumination during the pre-looming period, with the reverse occurring during the post-retrogression period. However, this pattern was weak, as no significant pair-wise differences were detected by our multiple comparison procedures (Tukey's test).

\section{Pacific halibut and lingcod}

Under low ambient illumination Pacific halibut were closer to the barrier than under high illumination (Fig. 5). There was no movement in response to either looming or retrogression and no statistical analyses were conducted. Similarly, lingcod changed position 


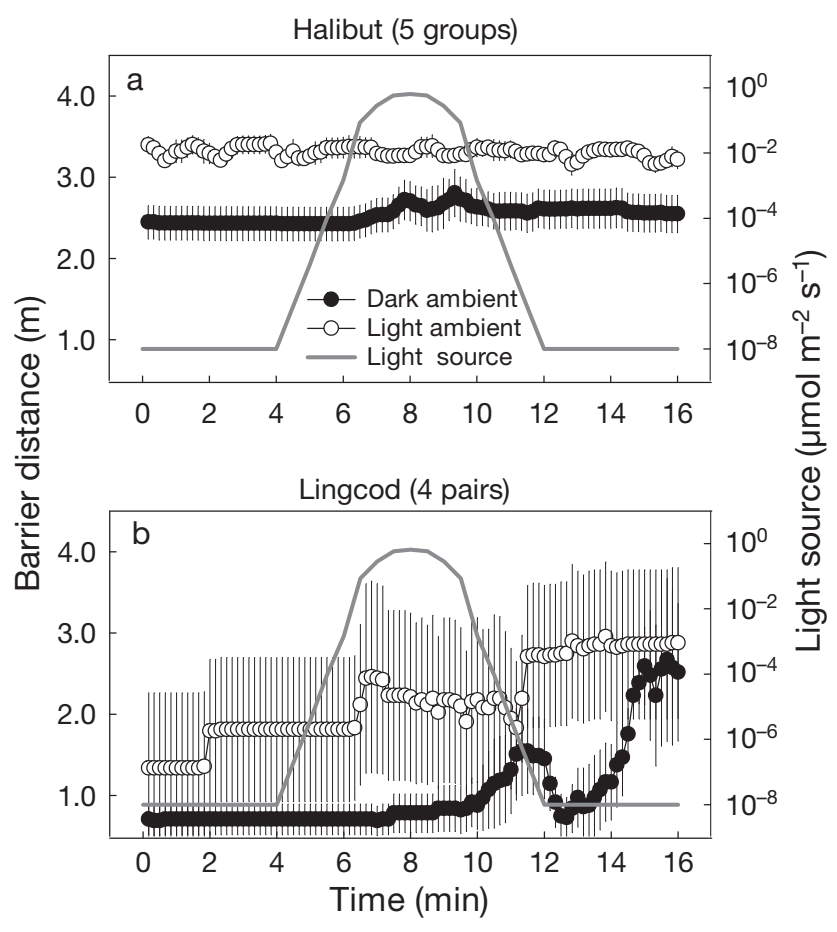

Fig. 5. Hippoglossus stenolepis and Ophiodon elongatus. Mean distance $( \pm \mathrm{SE})$ to transparent barrier for (a) Pacific halibut and (b) lingcod during pre-looming (0 to $4 \mathrm{~min}$ ), looming (4 to $8 \mathrm{~min}$ ), retrogression ( 8 to $12 \mathrm{~min}$ ) and post-retrogression (12 to $16 \mathrm{~min})$ periods, under both low $\left(6.38 \times 10^{-5} \mu \mathrm{mol}\right.$ photons $\left.\mathrm{m}^{-2} \mathrm{~s}^{-1}\right)$ and high ambient $\left(2.05 \times 10^{-3} \mu \mathrm{mol}\right.$ photons $\mathrm{m}^{-2}$ $\mathrm{s}^{-1}$ ) illumination. For both panels, light levels attributable to the looming light source (ambient light absent) are plotted in gray and numerated on the right-hand $y$-axis

little during the looming sequence. Lingcod moved towards barrier near the end of retrogression (Tukey's test: $\left.F_{23,69}=2.72, \mathrm{p}=0.001\right)$. There was, however, no independent or interactive influence of ambient illumination (illumination: $F_{1,3}=1.25, \mathrm{p}=0.345$; illumination $\times$ time: $\left.F_{23,69}=1.19, p=0.287\right)$. During postretrogression, lingcod under low ambient illumination retreated from the barrier while those under high illumination did not (Tukey's test for illumination $\times$ time: $\left.F_{23,69}=1.99, \mathrm{p}=0.015\right)$.

\section{Inter-fish distance and structure use}

Analysis of inter-fish distance and distance to nearest structure (cement blocks) produced few significant effects of ambient light upon the intensity or timing of behavior and no strong direct responses to looming light; results are only briefly described here. CO, QB and lingcod did not demonstrate any differences in inter-fish distance or distance to structure as a function of time (looming and retrogression sequences) or ambient illumination. Inter-fish distances for black rockfish and blue rockfish were similarly unaffected. However, blue rockfish gradually moved farther from a structure during the course of the looming and retrogression sequence trials $\left(F_{15,60}=3.26, \mathrm{p}=0.001\right)$, regardless of ambient illumination. Black rockfish exhibited a similar change in structure affinity throughout pre-looming, looming and retrogression periods, but during the post-retrogression under low illumination they moved farther from a structure, while those under high illumination moved closer (interaction: $\left.F_{15,60}=3.16, \mathrm{p}=0.001\right)$.

\section{DISCUSSION}

It should not be surprising that some fish species avoid bright lights when acclimated to natural conditions of low ambient illumination. Novel stimuli often trigger avoidance, a tactic to avoid predation (Ryer 2008). Among the 7 species examined, reactions ranged from strong avoidance to no reaction whatsoever. This suggests a need to question whether 'species of interest' are likely to react to UV approach in a manner that will bias abundance estimates. Similarly, differential bias among species may lead to a distorted perception of community structure. Few studies have deliberately attempted to test whether fish are attracted, neutral to, or avoid approaching UVs. Trenkel et al. (2004) ran parallel visual strip transects using the ROV Victor 6000 with 2 different floodlight intensities. Despite the relatively small numbers of fish observed, North Atlantic codlings (Morinae) were detected in significantly greater numbers under low, as opposed to high, light levels, indicating active avoidance of the ROV when it employed the brighter lighting. In contrast, the cutthroat eel Synapobranchus kaupi was detected in greater numbers during high light transects, suggesting possible attraction, although detection probability bias under high illumination could not be ruled out. In a similar experiment, Trenkel et al. (2004) also found that vehicle speed influenced the reactive behavior of cutthroat eels and roundnose grenadiers Coryphaenoides rupestris as fewer individuals of both species were detected when the ROV was operated at double the normal speed. In another study, Lauth et al. (2004a,b) used a 'Canadian Perspective Grid' technique (Wakefield \& Genin 1987) to analyze oblique video camera footage of the seafloor from a towed sled equipped with halogen lighting. They observed that thornyheads Sebastolobus spp. only moved out of the sled's path when it was close $(<1 \mathrm{~m})$ to avoid being run over, and concluded this response was unlikely to bias density estimates. Our results, combined with these field studies, suggest 
there may be considerable variation in the response of various fish species to approaching UVs.

Nominal activity of different fish species may play a significant role in how they respond to an approaching noxious stimulus. Sablefish were the most active species, as indicated by pre-looming activity levels, and displayed the strongest avoidance reaction. We have repeatedly observed that adult sablefish kept in holding tanks become easily agitated by disturbance, including abrupt changes in lighting, and are less prone to stress when held at low ambient illumination (C. Ryer pers. obs.). Similarly, the sablefish catch in pots equipped with either red or white lights is dramatically lower compared with control pots without lighting (Widder et al. 2005, K. Matteson pers. comm.). Among the species tested, sablefish are found at the greatest depths and are most common over low relief sedimentary seafloor at depths of 300 to $1000 \mathrm{~m}$ (Mecklenburg et al. 2002). Because the ambient illumination is low at these depths, we tested sablefish at our lowest ambient light level $\left(<1 \times 10^{-8} \mu \mathrm{mol}\right.$ photons $\left.\mathrm{m}^{-2} \mathrm{~s}^{-1}\right)$. As a consequence, light during the looming sequence increased from this level to $0.6 \mu \mathrm{mol}$ photons $\mathrm{m}^{-2} \mathrm{~s}^{-1}$ in 4 min. Nothing is known about light acclimation in the sablefish eye, but presumably this occurs through cone and/or pigment migration in the retinal epithelial tissue, as is the case for other teleost fishes, and requires longer than 4 min (Wagner 1990). Recent research demonstrates sudden exposure to bright light simulating daylight at the water's surface, without adequate time for acclimation, can temporarily or permanently reduce visual function in Pacific halibut (Brill et al. 2008). While the looming light to which we exposed sablefish was nearly 4 orders of magnitude lower than daylight, it appears to have constituted a noxious stimulus from which sablefish attempted to flee. The aforementioned thornyhead study (Lauth et al. 2004a,b) had been designed to survey sablefish, but sablefish were so rarely encountered that the authors concluded they were fleeing the approaching sled beyond the range of the cameras. The type of behavioral reaction, as well as the distance at which it occurs, is critical in determining the extent and direction of introduced bias in UV surveys (Stoner et al. 2008). Far-field avoidance is most likely to result in severe underestimation of fish density, suggesting that highly active species with vision adapted for low light conditions, such as sablefish, are poor candidates for such surveys.

The least active fish examined were Pacific halibut and lingcod. Both species use cryptic coloration as camouflage and remain motionless on the sediment or amongst rocks to ambush prey. For flatfishes, this detection minimization strategy predisposes them towards remaining motionless until a trawl, or predator, gets extremely close; typically a distance of $<1 \mathrm{~m}$
(Ryer 2008). Similarly, in areas where spearfishing is prohibited, lingcod resting on the bottom are easily approached (M. Spencer pers. obs.). Nest-guarding males can be approached closely enough to be measured and have fin tissue clipped before fleeing (Withler et al. 2004). Consequently, Pacific halibut and lingcod abundance estimates using UVs are unlikely to be biased by their movements. If any undercounting occurs, it would most likely be attributable to the cryptic nature of these fish.

How and when an approaching object is perceived should greatly influence how fish respond, as well as the time course of this response. An object becomes visible when its apparent contrast exceeds a physiological threshold (Lythgoe 1979). This 'contrast threshold will depend upon object size and its brightness relative to the surrounding environment (Anthony 1981). Importantly, over distance the natural light scattering properties of water and suspended and dissolved materials (turbidity) will degrade inherent contrast between distant light sources, such as a UV, and the surrounding environment. The farther away the object is, the greater the contrast degradation (De Robertis et al. 2003). Thus, in addition to the brightness of its lights, water characteristics will largely determine the distance at which a UV is first perceived by fish, and whether it is perceived as a glow in the distance or as a discrete point or points of light. Importantly, ambient illumination, through the same scattering process, will also contribute to contrast degradation. Therefore, an approaching UV carrying artificial lights will probably be less visible to fish and detected later during approach when ambient illumination is high; the importance of this being that fish may respond differently with depth or time of day.

While more reactive than lingcod and Pacific halibut, the 4 rockfish species we examined were still considerably less responsive than sablefish, and have generally been characterized as displaying weak responses unlikely to bias abundance estimates (Stein et al. 1992). Although variation among species existed, what was most noteworthy was the role that ambient illumination played in modulating the response for 2 of these species. Black rockfish and blue rockfish retreated from the looming light under both ambient illuminations; however, the onset of this avoidance was delayed under high illumination. As adults, both species form schools or shoals adjacent to or over a kelp forest and high relief terrain, most commonly at depths from near surface to 55 and $90 \mathrm{~m}$ for black rockfish and blue rockfish, respectively (Love et al. 2002). As a consequence both occur at depths where diel variation in ambient illumination (i.e. day versus night) would occur. If movements of these fish were to carry them beyond the range of view of a UV, then when this 
response occurs could be critical in determining the extent of any bias. Our results suggest potential for such bias would be greatest during nighttime. Copper rockfish and quillback rockfish, commonly encountered singly or in small aggregations (2 to 6 fish) (Johnson et al. 2003) at 10 to $90 \mathrm{~m}$ above areas with high relief bottom (Love et al. 2002), also moved away from the looming light; however, ambient illumination did not significantly modify this response.

Although not germane to the issue of detection bias, fish may actually follow UVs (Stoner et al. 2008). Yellowtail rockfish Sebastes flavidus were observed to persistently follow the ROV 'ROPOS.' We incorporated the retrogression sequence to simulate the retreating light of a UV after it had 'passed-by' fish. However, we saw little evidence of this following effect. Among the species examined there was generally relaxation of avoidance during the retrogression sequence, rather than actual attraction for the diminishing light source.

We have purposely avoided defining response thresholds for the various species examined. The amount of light detected by a light meter gives little insight into how an object is perceived, which will be determined, in part, by the luminosity of the object relative to its background. Such measurements were beyond our technical capability. Furthermore, light scattering and absorptive properties of water in the field will modify this perception. While we cannot tell a researcher precisely how far away fish may respond, we nonetheless feel our work has relevance for understanding possible bias that may occur due to fish behavioral reactions to UVs and has tentatively identified fish characteristics and environmental factors that may influence fish responsiveness to UV approach. It may be possible to reduce avoidance reactions by using light spectra for which fish have low sensitivity. Infrared is generally not perceived by fish (John 1964, Pitcher \& Turner 1986, Higgs \& Fuiman 1996) and attenuates too rapidly to be of use. However, many coastal fishes are insensitive to wavelengths below $420 \mathrm{~nm}$ (Lythgoe \& Partridge 1991, Lythgoe et al. 1994), raising the possibility that blue lights $(<420 \mathrm{~nm})$ on UVs might allow fish to be viewed without fish reactions to the UV's lights, although sound avoidance must still be assessed.

Our experimental results, in combination with earlier synthesis of field observations (Stoner et al. 2008), indicate that the probability of bias in visual surveys introduced through fish behavior will be highest in the species exhibiting high nominal activity, but low for more sedentary demersal species, such a flatfishes and lingcod; although cryptic behavior may still be of concern. Most fish species of interest to researchers using UVs will probably fall somewhere in the middle, and may display subtle behavioral responses capable of introducing bias to visual surveys. Pacific rockfishes, encompassing numerous species with variable distributions and behavior, may be a perfect example of this middle ground. While few surveys have incorporated a rigorous test for the key assumption that fish behavior is independent of the underwater vehicle or observer, a systematic evaluation of submersible-related bias was conducted by Yoklavich et al. (2007) for cowcod Sebastes levis. Their results suggest that this sedentary and non-schooling species can be surveyed without bias. Our results would suggest that other rockfish species should be similarly and systematically assessed. We further suggest that greater attention be focused upon ambient illumination and its potential influence upon behavioral reactions of fishes to UVs. Small differences in responsive behavior attributable to illumination, particularly if it occurs at great distance, may significantly compromise the comparability of surveys done at different depths or times of day. While all survey methods have certain inherent biases, it will be important to assess potential biases in visual direct count surveys conducted with UVs, understand the limitations for species that respond strongly or in the far-field, and standardize methods to minimize unintended variation in bias.

Acknowledgements. We thank J. Burke, K. Clifford, B. Fodness, E. Mochon-Collura and the Oregon Coast Aquarium for the loan of aquarium specimens. P. Rankin of the Oregon Department of Fisheries and Wildlife collected and facilitated transfer of the lingcod. K. Boersma assisted with video analysis. S. Haines, R. Titgen and M. Ottmar assisted in the care of fish, construction of apparatus and light measurements. C. Sweitzer assisted in manuscript preparation.

\section{LITERATURE CITED}

Adams PB, Butler JL, Baxter CH, Laidig TE, Dahlin KA, Wakefield WW (1995) Population estimates of Pacific coast groundfishes from video transects and swept-area trawls. Fish Bull 93:446-455

Anthony PD (1981) Visual contrast thresholds in cod Gadus morhua L. J Fish Biol 19:87-103

Auster PJ (1985) Aspects of American lobster, Homarus americanus, catch in baited traps. Connecticut Sea Grant Technical Bulletin Series CT-GS-85-1

Brill RW, Magel C, Davis MW, Hannah RW, Rankin PS (2008) Effects of rapid decompression and exposure to bright light on visual function in black rockfish (Sebastes melanops) and Pacific halibut (Hippoglossus stenolepis). Fish Bull 106:427-437

> De Robertis A, Ryer CH, Velosa A, Brodeur RD (2003) Differential effects of turbidity on prey consumption of piscivorous and planktiviorous fish. Can J Fish Aquat Sci 60: $1517-1526$

Dickson W (1993) Estimation of the capture efficiency of trawl gear. I: Development of a theoretical model. Fish Res 16: 239-253

> Domenici P (2002) The visually mediated escape response in fish: predicting prey responsiveness and the locomotor 
behaviour of predators and prey. Mar Freshw Behav Physiol 35:87-101

Handegard NO, Thøstheim D (2005) When fish meet a trawling vessel: examining the behaviour of gadoids using a free-floating buoy and acoustic split-beam tracking. Can J Fish Aquat Sci 62:2409-2422

Handegard NO, Michalsen K, Tjøstheim D (2003) Avoidance behaviour in cod (Gadus morhua) to a bottom trawling vessel. Aquat Living Resour 16:265-270

Higgs DM, Fuiman LA (1996) Light intensity and schooling behaviour in larval gulf menhaden. J Exp Biol 199: 2619-2629

John KR (1964) Illumination, vision, and schooling of Astyanax mexicanus (Fillipi). J Fish Res Board Can 21: 1453-1473

> Johnson SW, Murphy ML, Csepp DJ (2003) Distribution, habitat and behavior of rockfishes, Sebastes spp., in nearshore waters of southeastern Alaska: observations from a remotely operated vehicle. Environ Biol Fishes 66: $259-270$

Krieger KJ, Sigler MF (1996) Catchability coefficient for rockfish estimated from trawl and submersible surveys. Fish Bull 94:282-288

Lauth RR, Ianelli J, Wakefield WW (2004a) Estimating the size selectivity and catching efficiency of a survey bottom trawl for thornyheads, Sebastolobus spp. using a towed video camera sled. Fish Res 70:27-37

Lauth RR, Wakefield WW, Smith K (2004b) Estimating the density of thornyheads, Sebastolobus spp., using a towed video camera sled. Fish Res 70:39-48

Love MS, Yoklavich M, Thorsteinson L (2002) The rockfishes of the northeast Pacific. University of California Press, Los Angeles

Lythgoe JN (1979) The ecology of vision. Clarendon Press, Oxford

Lythgoe JN, Partridge JC (1991) The modeling of optimal visual pigments of dichromatic teleosts in green coastal waters. Vision Res 31:361-371

Lythgoe JN, Muntz WRA, Partridge JC, Shand J, Williams DM (1994) The ecology of the visual pigments of snappers (Lutjanidae) on the Great Barrier Reef. J Comp Physiol A Sens Neural Behav Physiol 174:461-467

Mecklenburg CW, Mecklenburg TA, Thorsteinson LK (2002) Fishes of Alaska. American Fisheries Society, Bethesda, MD

Paglianti A, Domenici P (2006) The effect of size on the timing of visually mediated escape behaviour in staghorn sculpin Leptocottus armatus. J Fish Biol 68:1177-1191

Petrie ME, Ryer CH (2006) Hunger, light level and body size affect refuge use by post-settlement lingcod Ophiodon elongatus. J Fish Biol 69:957-969

Pitcher TJ, Turner JR (1986) Danger at dawn: experimental support for the twilight hypothesis in shoaling minnows. J Fish Biol 29:59-70

Popper AN (2003) Effects of anthropogenic sounds on fish. Fisheries 28(10):24-31

Ryer CH (2008) A review of flatfish behavior relative to trawls. Fish Res 90:138-146

Ryer CH, Barnett LAK (2006) Influence of illumination and

Editorial responsibility: Antony Underwood,

Sydney, Australia temperature upon flatfish reactivity and herding behavior: potential implications for trawl capture efficiency. Fish Res 81:242-250

Ryer CH, Olla BL (1998) Effect of light on juvenile walleye pollock shoaling and their interaction with predators. Mar Ecol Prog Ser 167:215-226

> Ryer CH, Olla BL (1999) Light-induced changes in the prey consumption and behavior of two juvenile planktivorous fish. Mar Ecol Prog Ser 181:41-51

Schiff W, Caviness JA, Gibson JJ (1962) Persistent fear responses in rhesus monkeys to the optical stimulus of 'looming'. Science 136:982-983

Stein DL, Tissot BN, Hixon MA, Bariss WH (1992) Fish-habitat associations on a deep reef at the edge of the Oregon continental shelf. Fish Bull 90:540-551

Stoner AW (2004) Effects of environmental variables on fish feeding ecology: implications for the performance of baited fishing gear and stock assessment. J Fish Biol 65: 1445-1471

Stoner AW, Ryer CH, Parker SJ, Auster PJ, Wakefield WW (2008) Evaluating the role of fish behavior in surveys conducted with underwater vehicles. Can J Fish Aquat Sci 65: 1230-1243

Trenkel VM, Lorance P, Mahévas S (2004) Do visual transects provide true population density estimates for deepwater fish? ICES J Mar Sci 61:1050-1056

Uzmann JR, Cooper RA, Theroux RB, Wigley RL (1977) Synoptic comparison of three sampling techniques for estimating abundance and distribution of selected megafauna: submersible vs camera sled vs otter trawl. Mar Fish Rev 39:11-19

Vabø R, Olsen K, Huse I (2002) The effect of vessel avoidance of wintering Norwegian spring spawning herring. Fish Res 58:59-77

Wagner HJ (1990) Retinal structure of fishes. In: Douglas RH, Djamgoz MBA (eds) The visual system of fish. Chapman and Hall, London, p 109-157

- Wakefield WW, Genin A (1987) The use of a Canadian (perspective grid) in deep-sea photography. Deep-Sea Res 34: 469-478

Widder EA, Robison BH, Reisenbichler KR, Haddock SHD (2005) Using red light for in situ observations of deep-sea fishes. Deep-Sea Res 52:2077-2085

Withler RE, King JR, Marliave JB, Beaith B, Li S (2004) Polygamous mating and high levels of genetic variation in lingcod, Ophiodon elongatus, of the Strait of Georgia, British Columbia. Environ Biol Fishes 69:345-357

Woodhead PMJ (1964a) A change in the normal diurnal pattern of capture of soles during the severe winter of 1963. Rapp P-V Réun Cons Perm Int Explor Mer 55:45-47

Woodhead PMJ (1964b) Changes in the behaviour of the sole, Solea vulgaris, during cold winters, and the relation between the winter catch and sea temperatures. Helgol Wiss Meeresunters 10:328-342

Yoklavich MM, Love MS, Forney KA (2007) A fisheries-independent assessment of an overfished rockfish stock, cowcod (Sebastes levis), using direct observations from an occupied submersible. Can J Fish Aquat Sci 64: 1795-1804

Submitted: November 21, 2008; Accepted: June 17, 2009 Proofs received from author(s): September 11, 2009 